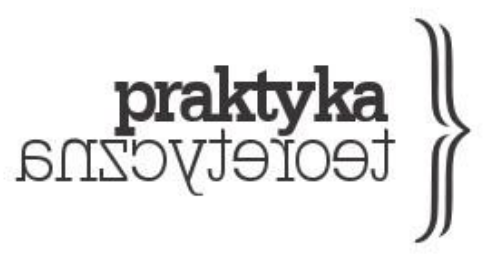

ISSN 2081-8130

DOI: $10.14746 /$ prt.2016.4.9 www.praktykateoretyczna.pl

\title{
JEŚLI MÓWIĆ PRAWDĘ, TO TYLKO W SIERPNIU. ETYKA JAKO POLITYKA
}

\section{CEZARY RUDNICKI}

\begin{abstract}
Abstrakt: Niniejszym artykułem chciałbym dołączyć swój głos do podjętej przez Jana Sowę próby odzyskania dla lewicy fenomenu „Solidarności”. Równocześnie podobnego zabiegu odzyskiwania pragnę dokonać na myśli „późnego” Michela Foucaulta. O ile koncepty takie jak dyscyplina i biopolityka, metoda genealogicznej analizy relacji władzy, a nawet pojęcie przedsiębiorcy samego siebie zostały przez lewicę bardzo szybko przyswojone, o tyle z jakichś niezrozumiałych dla mnie powodów rozważania skupione wokół problematyki „troski o siebie i innych” traktowane są na ogól jako, co najwyżej, ciekawostka. To milczenie zostało wykorzystane przez liberalnych komentatorów Foucaulta, a także jako fundament dla neokonserwatywnego projektu Petera Sloterdijka (którego rdzeń został przedstawiony w obszernym eseju Musisz życie swe odmienić. O antropotechnice). Rzecz tym bardziej niepokojąca, iż to właśnie w etyce Siebie Foucault widział najważniejszy punkt oporu wobec neoliberalizmu. Dokonana w poniższym tekście analiza wydarzeń Sierpnia '80 za pomoca niektórych pojęć opracowanych przez francuskiego filozofa w latach 1980-1984 jest zarazem próbą wskazania ich użyteczności dla rewolucyjnych praktyk i teorii.
\end{abstract}

Słowa kluczowe: parezja, Sierpień '80, etyka, Solidarność, Foucault, praktyki siebie 


\section{Foucault a „sprawa polska”}

Chociaż wybór Foucaultowskiej „skrzynki z narzędziami” do analizy Sierpnia '80 został podyktowany względami naukowymi, warto wspomnieć o znaczeniu, jakie dla francuskiego filozofa miała sytuacja w Polsce lat 80. Tym bardziej, że zdaje się ona bezpośrednio oddziaływać na niektóre z jego poszukiwań teoretycznych (zob: Hoffman 2014, 124-126, 129-135). Michel Foucault był bardzo mocno zaangażowany w „sprawę polską”, szczególnie w okresie od końca 1981 do końca 1982 roku. Na jego aktywność składały się nie tylko takie drobiazgi jak noszenie przez kilka miesięcy przypinki z logiem „Solidarności”, ale również udział w licznych akcjach poparcia dla polskiego związku zawodowego, przede wszystkim tych organizowanych przez CFDT $^{1}$, a nawet podróż - we wrześniu 1982 roku - do objętej stanem wojennym Polski. Nie sposób zapomnieć również o gwałtownej reakcji Foucaulta na potraktowanie przez rząd francuski stanu wojennego, wprowadzonego 13 grudnia 1981 roku, jako wewnętrznej sprawy Polski, niewymagającej żadnej ingerencji. Francuski filozof nie tylko natychmiast ostro skrytykował ministra spraw zagranicznych Claude’a Cheyssona (który przedstawił stanowisko rządu), ale już następnego dnia rozpoczął - wraz z Pierre'em Bourdieu - prace nad nieprzychylnym wobec władz oświadczeniem. Warto jednak zauważyć, że autorzy monografii o Foucaulcie marginalizuja - lub wręcz ignoruja - owo zaangażowanie. Jak słusznie zauważa Marcelo Hoffman: „To milczenie nie pozostaje bez implikacji”" (Hoffman 2014, 126). Służy ono różnego rodzaju celom interpretacyjnym.

Nie tylko nie sposób tego zrobić, ale i bezcelowe byłoby wymienianie wszystkich opracowań, które nie wspominają o Foucaultowskim poparciu dla „Solidarności”. Przywołam jedynie dwa z nich, aby zilustrować najczęstsze powody owego milczenia. Z jednej strony, jak w przypadku książki Foucault 2.0: Beyond Power and Knowledge (Paras 2006), takie pominięcie pozwala bronić tezy o swego rodzaju wycofaniu się Foucaulta z polityki po „porażce” jego zaangażowania w Rewolucję Irańska. Wedle Erica Parasa późny Foucault wykracza poza władzę, tzn. uznaje, że podmiot nie jest wytworem relacji władzy, lecz preegzystuje wobec nich - oznaczałoby to całkowite odstapienie od stanowiska wyrażonego w Nadzorować $i$ karać oraz Woli wiedży. Podobny zabieg stosuje zresztą wspomniany już Sloterdijk, wedle którego autor wymienionych książek uwolnił się pod koniec życia „od paranoidalnych resztek swoich własnych badań nad władzą” (Sloterdijk 2014, 213).

\footnotetext{
1 Confédération française démocratique du travail, czyli Francuską Demokratyczną Konfederację Pracy. (Jeden z przedstawicieli CFDT przybył do Stoczni Gdańskiej - z deklaracją wsparcia oraz darowizną - już 26 sierpnia 1980 roku). Warto zaznaczyć, że wspólne zaangażowanie CFDT oraz francuskich intelektualistów było przyczynkiem do nawiązania dłuższej współpracy pomiędzy tymi dwiema grupami. Skalę i znaczenie tej współpracy prezentuje wspaniały - i niezwykle pouczający - wywiad, jaki Foucault przeprowadził w 1983 roku z ówczesnym sekretarzem generalnym CFDT, Edmondem Maire; zob.: Foucault 2013b.
} 
Wedle tego niemieckiego filozofa wszystkie dzieła Foucaulta, pomiędzy napisanym przez niego wprowadzeniem do francuskiego wydania książki Traum und Existenz Ludwiga Binswangera a drugim i trzecim tomem Historii seksualności, wymagają jeśli nie wręcz zignorowania, to przynajmniej gruntownej reinterpretacji. Z drugiej strony, owo milczenie na temat zaangażowania francuskiego filozofa w sprawę polską służy do pozbycia się niewygodnego argumentu podważającego liberalne odczytania jego myśli. Przykładowo Alain Beaulieu przerywa swoją niezwykle rzetelną analizę związków pomiędzy politycznym aktywizmem Foucaulta a jego pracą teoretyczną dokładnie w tym miejscu, w którym mogłoby to zagrozić jego tezie (Beaulieu 2010, 806-811) o liberalizmie jako najlepszym środowisku dla transformacji relacji władzy przenikających społeczeństwo.

Celem niniejszego artykułu nie jest polemika ze wspomnianymi wyżej interpretacjami. Przywołuje je jednak nie tylko po to, aby się względem nich zdystansować, ale przede wszystkim po to, aby wyczulić czytelnika na porozsiewane w niniejszym artykule analizy, tezy oraz odwołania do faktów, które razem wzięte stanowią zestaw silnych kontrargumentów. Przede wszystkim chodzi jednak o zapowiedziane na początku odzyskanie Foucaulta dla lewicy. To zaś wymaga, w moim przekonaniu, nakreślenia szerokiej panoramy „późnej” myśli tego filozofa, dzięki czemu możliwe będzie prawidłowe ulokowanie pojęć werydykcji i parezji, kluczowych dla przeprowadzanych w tym tekście analiz.

\section{Praktyki Siebie (o przyjętej tu metodzie)}

Pod koniec swojego życia autor Historii seksualności często podkreślał, że tym, co go zajmowało w ostatnich latach - a nawet zajmowało zawsze - była relacja pomiędzy podmiotem a grami prawdy (Foucault 2013a, 211). Przy czym kwestię prawdy od razu odnosił on do problematyki politycznej, stawiając sobie za cel wypracowanie „pojęcia rządzenia ludźmi za pomoca prawdy” (Foucault 2014, 32). Pierwsze działania w tym kierunku zostały podjęte w cyklu wykładów zatytułowanym Narodżiny biopolityki, wygłoszonym w roku akademickim 1978-1979. Przedsięwzięte wówczas studia nad liberalizmem miały za zadanie wyjaśnić „nagłe wyłonienie się rynku jako zasady orzekania prawdy” (Foucault 2011, 56), a ich zwieńczeniem było wypracowanie pojęcia specyficznego typu upodmiotowienia (tj. przedsiębiorcy samego siebie) będącego korelatem neoliberalnej techniki rządzenia. Jednak w moim przekonaniu lepszym - niż "gry prawdy” - terminem organizujacym myśl późnego Foucaulta jest ,etyka”.

We wstępie do U⿺辶̀ytku z prayjemności francuski filozof wykazuje, że termin „moralność” możemy rozumieć na kilka sposobów. Przede wszystkim jako „moralność 
zachowań", tzn. jako faktyczne czyny dokonywane przez konkretne jednostki. Jest to codzienny sposób użycia tego terminu, najmniej interesujący filozoficznie. Dziedzina takich jednostkowych zachowań jest obszarem badań raczej psychologa albo historyka moralności filozofowi służy co najwyżej jako kolekcja przykładów albo problemów. Wedle drugiego, filozoficznego znaczenia moralność jest zespołem wartości, ocen i norm oraz zasad i reguł dotyczących postępowania. Można by powiedzieć: tak rozumiana moralność to kodeks mimo że nie zawsze występuje w postaci spisanej. Przynależne do kodeksu moralnego wartości i zasady mają strukturę jurydyczną: są zakazami i nakazami, jawią się jako „trzeba...”, jako obowiązki albo wręcz jako „rozkazy” (to ostatnie określenie pochodzi od Spinozy). Jednak również podstawowe pojęcia moralne odsyłają do porządku prawnego. Jak zauważa Giorgio Agamben: „Nieomal wszystkie kategorie, którymi zwykliśmy się posługiwać w dziedzinie moralności i religii, są w większym lub mniejszym stopniu skażone znaczeniem prawnym: wina, odpowiedzialność, niewinność, sąd, darowanie winy" (Agamben 2008, 16). Tę charakterystykę należy uzupełnić o jeszcze jeden aspekt - transcendencję. Moralne wartości i zasady są czymś zewnętrznym w stosunku do jednostek oraz czynów, w związku z czym przypisuje się im również cechę niezmienności i uniwersalności.

Foucault zauważa jednak, że w ramach domeny moralnej mieści się coś jeszcze, czego nie da się opisać ani w kategoriach prawa, ani jako konkretnych postępków. Objaśnia to na przykładzie etycznej zasady ścisłej i symetrycznej wierności małżeńskiej. Otóż może być ona praktykowana na różne sposoby, można w różny sposób być wiernym.

I tak można oprzeć istotę praktykowania wierności na czystym poszanowaniu zakazów i zobowiązań w odniesieniu do swoich czynów. ПJest to przypadek etyki kantowskiej: szacunek dla prawa moralnego - przyp. CR]. Ale można też budować istotę wierności na opanowaniu pragnień, na wypowiedzianej im zaciekłej walce, na sile, z jaką człowiek potrafi oprzeć się pokusie - treścią wierności jest wówczas owa czujność i walka; nie same czyny i ich spełnianie, ale raczej sprzeczne porywy duszy będące w tych warunkach materia praktyki moralnej. [To przypadek etyki mający swe korzenie w chrześcijańskim monastycyzmie (asceza rozumiana jako walka z pragnieniem) - przyp. CR]. Prócz tego można budować ją na intensywności, ciagłości i wzajemności uczuć żywionych wobec małżonka, na jakości związku nieustannie wiążącego małżeństwo [Ten trzeci przypadek można by nazwać etyka „romantyczną” - przyp. CR] (Foucault 2010b, 128).

Ta sama reguła na poziomie kodeksu, „ten sam” efekt na poziomie działania, ale zupełnie różne praktyki pośredniczące. Z przyjętej przez Foucaulta perspektywy to one są 
najważniejsze, gdyż w gruncie rzeczy nie istnieje żaden pojedynczy czyn moralny, lecz zawsze występuje pewna całość zachowania moralnego, która rodzi za każdym razem inne całościowe efekty. Nieco upraszczając, można powiedzieć, że w pierwszym wypadku owym efektem jest podmiot posłuszny, w drugim ascetyczny, zaś w trzecim - uczuciowy. Za każdym razem stosunek takiego podmiotu do świata, a przede wszystkim reakcja na to, co w świecie napotkane, oraz projektowanie własnych celów, działań, posunięć będa inne i to pomimo podporządkowania się temu samemu kodeksowi moralnemu.

Ujmując rzecz jeszcze inaczej: nie istnieje proste przełożenie regul na czyny, tzn. jakiś automatyzm moralny, w ramach którego zasady byłyby stosowane w sposób mechaniczny czy też bezpośredni. Jednostka działa moralnie nie tylko jako agens będący jedynie nośnikiem jakiegoś zbioru wartości i zasad, ale również jako podmiot moralny, jako pewna funkcjonalna całość. O tyle lepiej mówić tu o sferze upodmiotowienia moralnego czy też etycznego. Chociaż sam Foucault pisze o dwóch różnych typach moralności (nakierowanej na kodeks i nakierowanej na etykę), to ja wolę mówić o różnicy między moralnością a etyka. Tak jak do moralności (w węższym sensie) przynależy ustrukturyzowany jurydycznie system zasad i wartości, tak do etyki zaliczaja się różne formy oddziaływania jednostki na samą siebie, za pomocą których ustanawia się ona jako ów wspomniany podmiot zachowania moralnego (w szerszym sensie). Owo oddziaływanie zależy od wielu czynników, które Foucault porządkuje w następujące grupy: określenie substancji etycznej (tego dotyczył przykład wierności), wybór sposobu ujarzmienia, forma pracy etycznej oraz rodzaj teleologii. Można by je nazwać razem etyczną pracą jednostki nad samą sobą. Chodzi o to, że moralność (ponownie, w szerszym sensie) nie sprowadza się do pewnego czynu czy serii czynów podporządkowanych systemowi wartości, ale wymaga również pewnego określonego sposobu bycia. Aby go wykształcić, jednostka musi działać na sobie samej, poznawać siebie, kontrolować się, doświadczać, doskonalić, zmieniać. Przyjmując w niniejszym artykule perspektywę etyczną, rozważam nie normy, wartości i zasady postępowania, ale procedury, techniki, ćwiczenia oraz zabiegi odpowiedzialne za kształtowanie sposobu bycia, za nadawanie jednostce określonej struktury podmiotowej ${ }^{2}$.

Przed przejściem do kwestii mówienia prawdy pozwolę sobie jeszcze na krótką wycieczkę w rejony filozofii polityki. Drugi i trzeci tom Historii seksualności, opublikowane na kilka tygodni przed śmiercią Foucaulta, w niewielkim tylko stopniu prezentuja jego studia nad etyką i filozofia polityki. O wiele lepszym źródłem wiedzy na ten temat sa transkrypcje wykładów wygłaszanych przez niego w Collège de France. W czasie jednego z nich, mającego

\footnotetext{
2 Nie rozwijając tego wątku, zaznaczam jedynie, że etykę rozumiem jako pojęcie szersze niż moralność. W moim przekonaniu ta ostatnia również wymaga pewnego określonego typu upodmiotowienia (nazywam je mianem quasi-jurydycznego), tzn. takiego, które polega na podporządkowaniu się kodeksowi i ćwiczeniu się w posłuszeństwie.
} 
miejsce 2 lutego 1983 roku, Foucault wprowadza pewną dystynkcję pojęciową (zob.: Foucault 2010a, 158-159), do której później - nie licząc dwóch krótkich wzmianek - już explicite nie wraca. Jest to różnica pomiędzy politeia a dynasteia - w moim przekonaniu można ja potraktować jako analogiczna do podziału na moralność i etykę. Politeia oznacza wszystkie kwestie związane z konstytuowaniem się wspólnoty oraz jej prawa. Jest to polityka rozumiana jako walka o typ ustroju politycznego przyjętego przez daną społeczność, jako walka o obowiązujące prawo albo konstytucję. Istnieje jednak jeszcze inny aspekt polityki, opisywany przez pojęcie dynasteia. Oznacza ono grę polityczna, czyli wszelkiego rodzaju kwestie związane $z$ formowaniem, sprawowaniem i granicami władzy nad innymi obywatelami oraz konkretne procedury i techniki sprawowania tej władzy. Pojęcie to odsyła również do problematyki dotyczącej „natury” człowieka zajmującego się polityką - jego charakteru, cech, jego relacji do siebie i innych, jego etycznego prowadzenia się, jego etosu. Każdy z tych obszarów tego, co polityczne, wymaga odrębnego typu analizy. Politeia odsyła do refleksji nad natura prawa, organizacja społeczeństwa oraz tym, jakie powinno być państwo. Natomiast dynasteia odsyła do rozważań nad kwestiami czysto politycznymi: racjonalnością polityki, jej relacją do prawdy oraz charakterem tych, którzy grają w grę polityczną. Politeia to jurydyczno-instytucjonalny system społeczeństwa, natomiast dynasteia to immanentne społeczeństwu relacje władzy, które sprawiaja, że podlega ono takim, a nie innym technikom rządzenia ${ }^{3}$. Gdy w dalszej części tego artykułu będę wspominał o związku etyki i polityki, to tę ostatnią będę zwykle rozważał w tym jej aspekcie, który określa pojęcie dynasteia.

\section{Werydykcja}

Foucaultowskie studia nad antyczną etyką cechuje niezwykłe bogactwo - nie tylko konstruuje on z pojęć takich jak troska o siebie, nawrócenie się na siebie czy estetyka egzystencji złożoną siatkę teoretyczna, ale ponadto rozważa mnogość konkretnych technik siebie (takich jak rachunek sumienia, procedury próby czy medytacja nad śmiercią). Spośród tego ogromnego zbioru wybieram jeden wątek: werydykcję, czyli praktykę mówienia prawdy.

Nasza relacja do prawdy nie ogranicza się wyłącznie do aspektów poznawczych, tzn. nie polega tylko na dostępie do prawdy lub jego braku, problemach związanych z jej rozpoznaniem oraz na akceptacji lub nieakceptacji prawdy. Przede wszystkim relacja z prawda

\footnotetext{
3 W podziale tym można również dostrzec pewien wariant rozwijanej przez Foucaulta od lat różnicy pomiędzy jurydyczno-dyskursywną koncepcją władzy a analizą rozmaitych technik rządzenia. Ujawnia się tu zatem łącznik pomiędzy jego „środkową” a „późną” myślą.
} 
może mieć pewien wymiar praktyczny, doskonale widoczny w wielości sposobów wypowiadania prawdy. Przykładowo nauczanie „techniczne”, tzn. nauczanie określonej techne, pewnego know-how: nie tylko wymaga mówienia prawdy, ale w pewien sposób zobowiązuje do mówienia. Nauczyciel to ktoś, kto sam uzyskał wiedzę dzięki nauczaniu prowadzonemu przez innego, w związku z czym ma niejako obowiązek kontynuować ten proces, przekazać wiedzę dalej. Do tego musi mówić w sposób przystępny, zrozumiały (zob.: Foucault 2012, 23-24). Różni go to na przykład od mędrca, który z jednej strony nie ma obowiązku mówienia prawdy (może zachować swą wiedzę dla siebie), z drugiej zaś, jeśli już mówi prawdę, może ja wypowiadać w sposób enigmatyczny. Ponadto nauczyciel mówi raczej o konkretnych faktach i regułach, mędrzec zaś o ogólnych zasadach (zob.: Foucault 2012, 16-18). Wreszcie nauczyciel mówi prawdę niejako w imieniu tradycji, natomiast mędrzec we własnym imieniu (nawet jeśli inspiruje go tradycja). Jeszcze inny rodzaj werydykcji prezentuje wieszcz, który mówi w imieniu bóstwa, do tego zwykle w sposób enigmatyczny (zob.: Foucault 2012, 15-16). Każdy z nich mówi prawdę, ale wedle odmiennego modusu. Należy mocno podkreślić tę kwestię: mimo że opowiadając o każdym z tych typów werydykcji, przywołałem jakąś postać (nauczyciela, wieszcza czy mędrca), to nie należy myśleć tu o jakichś profesjach czy typach społecznych. Są to wyłącznie różne modalności mówienia prawdy, które mogą łączyć się w różne sposoby lub występować w jednej postaci (Foucault jako przykład podaje tu Sokratesa).

Autor Historii seksualności szczególną uwage poświęca jednak temu typowi werydykcji, jakim jest parezja (gr. parrēsia). W najbardziej dosłownym przekładzie parrēsia to „mówić wszystko”, oznacza ona szczerość oraz wolność mówienia, swobodne mówienie. W antycznej etyce parezja funkcjonowała jako technika stosowana przez nauczyciela troski o siebie. Według starożytnych myślicieli etyczna praca nad sobą wymagała pomocy ze strony kogoś, komu będziemy mówili prawdę o sobie samych i kto na tej podstawie będzie stosował wobec nas parezję: wskazywał nam nasze słabości, zwracał uwagę na błędy, jakie popełniamy itp. Foucault zauważa, że przyzwyczajeni jesteśmy myśleć o tej postaci w kategoriach chrześcijańskich (jako o spowiedniku lub przewodniku duchowym) albo - bardziej współcześnie - jako o psychiatrze, psychologu lub psychoanalityku (Foucault 2012, 5-6). Nauczyciel troski o siebie nie ma jednak nic wspólnego z tymi „profesjami”; jego rola nie jest ani zinstytucjonalizowana, ani usankcjonowana odebranym wykształceniem - liczy się tylko to, by swym życiem wyrażał pewien etos. Jego zadaniem nie jest też ocena postępków „ucznia” pod kątem Dobra lub Zła, ale jedynie pod kątem skuteczności. Nauczyciel troski o siebie ma stosować parezje - mówić nam szczerze wszystko, również to, co niewygodne lub bolesne - po to, by skierować naszą uwagę na te czyny, które były błędne z perspektywy postawionych sobie przez nas celów. Formułuje swój dyskurs nie po to, by zwrócić nas ku naszej własnej przeszłości (np. dzieciństwu), w której pogrzebane są przyczyny naszych 
problemów, lub ku wyższym wartościom, którym powinniśmy się poświęcić. Przeciwnie, celem jego mowy jest umożliwienie nam nawrócenia się na samych Siebie 4 .

Jednakże oprócz etycznej parezja spełnia również funkcję polityczną. To pojęcie interesuje mnie właśnie z uwagi na ten jego podwójny, etyczno-polityczny aspekt. Parezji politycznej używa mówca przemawiający przed Zgromadzeniem, cynik zaczepiający mieszkańców miasta czy doradca zwracający się do Księcia. Wspólną cechą wszystkich tych sposobów mówienia prawdy jest to, że nie wypowiada się jej z pozycji uprzywilejowanej, lecz z pozycji podporządkowanej. Co za tym idzie, parezja polityczna wymaga odwagi - mówiący zawsze może ponieść konsekwencję swojej szczerości. W antyku oznaczało to, że mógł zostać wygnany z miasta lub nawet zabity. Mimo tego, mimo istnienia dla mówiącego zagrożenia, parezja może odbywać się tylko w ramach pewnej „gry”, w której odpowiednią postawę przyjmuje nie tylko ten, kto mówi, ale również ten, kto słucha. Aby możliwa była parezja, potrzeba słuchającego, musi on rozpoznać, że parezjasta kieruje do niego dyskurs oparty na prawdzie oraz musi tę prawdę (nie ważne jak przykrą i bolesna) akceptować. Owa akceptacja nie unieważnia jednak warunku drugiego, tzn. zagrożenia. To ostatnie funkcjonuje raczej jako pewien punkt graniczny: słuchający nie jest już w stanie dłużej znosić szczerości mówiącego i zrywa parezjastyczną grę, dokonując na parezjaście zemsty. Toteż nawet jeśli istnieją warunki dla mówienia i słuchania, to zagrożenie nigdy nie zostaje całkowicie usunięte.

Warto jeszcze wskazać różnicę pomiędzy parezją a dwoma innymi typami wypowiedzi: wypowiedzia naukową oraz performatywem. Performatywy (czyli wypowiedzi wywołujace skutki, takie jak „ogłaszam was mężem i żoną”) są zrelatywizowane do reguł instytucji, w ramach której się dokonuja, ponadto mówiący musi posiadać pewien autorytet. Z drugiej strony, wypowiedź naukowa czy - szerzej - wiedza formułowana jest zgodnie z określonymi regułami dyskursu (np. wymaga podporządkowania się pewnej metodzie). W przeciwieństwie do tego parezja to taki typ wypowiedzi, który jest do pewnego stopnia niezależny od autorytetu mówiącego i który wymyka się regułom wiedzy oraz instytucji ${ }^{5}$. Parezja ma

4 Brak tu miejsca na szerszą dyskusję tej kwestii, należy jednak zaznaczyć, że owo „Siebie” (fr. le sol) jest takim typem upodmiotowienia, który Foucault przeciwstawia dyscyplinarnemu ujarzmieniu oraz neoliberalnemu ,przedsiębiorcy samego siebie”.

5 W wykładzie z 12 stycznia 1983 roku Foucault wskazuje trzy różnice pomiędzy parezja a performatywem (ang. performative utterance, co czasem tłumaczy się jako „wypowiedź performatywna” bądź „wypowiedź wykonawcza”). Po pierwsze, choć parezja, podobnie jak performatyw, posiada pewną moc sprawczą (tzn. charakter illokucyjny), to jednak wywoływany przez nią efekt nie jest z góry określony; w przeciwieństwie do efektu performatywu, który jest ściśle zdeterminowany przez pewien kod i pole instytucjonalne, w ramach którego jest wypowiadany. Chcąc rzecz ując w takich kategoriach, można by powiedzieć, że parezja - inaczej niż wypowiedź performatywna - nie posiada aspektu prelokucyjnego lub też ma prelokucję nieokreśloną (za tę uwagę dziękuję Mikołajowi Ratajczakowi). Warto również zaznaczyć, że o ile wypowiedzi performatywne („przepraszam”, „ogłaszam was mężem i żoną”) nie są ani prawdziwe, ani fałszywe, o tyle parezja polega właśnie na wypowiedzeniu prawdy. Po drugie, aby wypowiedź performatywna zadziałała, podmiot wypowiedzenia musi posiadać określony status (np. być urzędnikiem stanu cywilnego albo 
charakter zdarzeniowy: nawet jeśli dokonuje się $w$ ramach jakiejś instytucji (np. zgromadzenia obywateli), to polega na zaburzeniu reguł tej instytucji. Parezja ma za zadanie wprowadzić różnicę, doprowadzić do jakieś zmiany, zerwać ze status quo. Właśnie dlatego wiąże się ona ze stałym zagrożeniem ${ }^{6}$.

\section{Negocjacje}

Wprowadzone dotąd narzędzia teoretyczne zostaną wykorzystane teraz do analizy przypadku Gdańskiego Sierpnia '80. Mam nadzieję, że tego rodzaju konfrontacja z materiałem empirycznym nie tylko wykaże przydatność Foucaultowskiej koncepcji werydykcji, lecz pozwoli również - w jej obrębie - na wypracowanie nowych pojecć lub przynajmniej wskazanie różnych wariantów tych już istniejących. W szczególności będą mnie interesowały negocjacje Międzyzakładowego Komitetu Strajkowego (MKS) ze stroną rządową. Zamierzam wyodrębnić najważniejsze grupy, które zabierały wówczas głos, dzieląc je z uwagi na typ mowy, jakim się posługiwały. Ponadto omówię relacje między nimi oraz warunki genezy takiej, a nie innej formy tychże relacji.

W pierwszej kolejności Prezydium MKS-u przemawiające w imieniu robotników i robotnic ${ }^{7}$. Na początek należy zaznaczyć jego nie-dominująca pozycję - strajkujący zwracali się do wicepremiera Mieczysława Jagielskiego czy ówczesnego dyrektora Stoczni, Klemensa Gniecha jako do przedstawicieli władzy. Mówili szczerze, często bez ogródek ${ }^{8}$ o tym, co myśla; wskazywali na to, że Partia wielokrotnie ich oszukała, nie dotrzymała swoich

osobą, która zawiniła wobec innej); zarazem to ten status wyznacza, co jednostka może i co musi powiedzieć. W przypadku parezji posiadanie jakiegoś określonego (zewnętrznego) statusu nie jest ani konieczne, ani istotne. Znaczenie ma natomiast jednostkowy charakter mówienia oraz wolność, jaką kieruje się mówiący, gdy postanawia zabrać głos. Po trzecie, w przypadku performatywu pomiędzy wypowiedzią a jednostką nie musi zachodzić żadna osobowa relacja: ksiądz wypowiadający słowa ,ja ciebie chrzczę...” może być w głębi duszy ateista, nie wpłynie to w żaden sposób na skuteczność chrztu i wynikająca z niego możliwość przyjmowania kolejnych sakramentów. Parezja wymaga natomiast od jednostki osobistego odniesienia do tego, co mówi - i to na dwóch poziomach. Na poziomie treści: parezjasta musi uważać za prawdziwą treść wypowiedzianego twierdzenia; na poziomie aktu: parezjasta musi akceptować akt wypowiedzenia, jakiego dokonał, oraz wszystkie płynące z niego konsekwencje (zob.: Foucault 2010a, 60-66).

6 Te charakterystyki parezji politycznej przekładają się, w odpowiedni sposób, na parezję etyczną (np. ona również wiąże się z pewną groźbą zerwania relacji, napięciem pomiędzy mówiącym a słuchającym).

7 W dalszej części tekstu piszę nieco więcej na temat owego „przemawiania w imieniu”.

8 Rolę odgrywał zresztą nie tylko dobór słów, ale również ich afektywne nacechowanie. To jeden z tych aspektów żywej mowy, którego nie oddają istniejące transkrypcje - można go doznać, dopiero odsłuchując nagrania z negocjacji. W głosie robotników niejednokrotnie pobrzmiewa irytacja, wzburzenie lub wręcz gniew. Jak stwierdza Foucault w wywiadzie, którego udzielił w październiku 1982 roku, tuż po powrocie z Polski: „rolą rządzonych jest w sumie wściekanie się i wlewanie pasji w swoje własne reakcje. Wierzę w wagę afektu politycznego" (Foucault, w przygotowaniu). 
obietnic albo uniemożliwiała im mówienie. W czasie negocjacji poruszali tematy zakazane przez cenzurę, takie jak Grudzień ’70, nieuczciwe procesy sądowe przeciwko działaczom robotniczym czy sytuacja gospodarcza kraju. Przykładowo w trakcie dyskusji na temat aresztowań Lech Wałęsa mówił do Jagielskiego:

\begin{abstract}
„Bo taka jest prawda, ogląaliśmy te procesy, ja byłem i jeszcze inni, i od razu moge powiedzieć, ponieważ jestem robotnikiem i nie liczę się ze słowami, że było to sfingowane". Natychmiastowy aplauz z sali delegatów uświadomił Jagielskiemu, że nie jest to opinia pojedynczego człowieka (Goodwyn 1992, 62).
\end{abstract}

Nawet jeśli strajkujący uciekali się czasem do ogólników, to zwykle natychmiast przywoływali bardzo konkretne przykłady. W tym wypadku wypowiedzi Wałęsy uzupełnił Florian Wiśniewski, opisując własne prześladowanie przez milicję. Należy zaznaczyć, że wszystkie fakty, o których mówili robotnicy i robotnice, nie funkcjonowały po prostu jako sądy adekwatne do stanu rzeczy (myślę, że nie posunę się za daleko, jeśli powiem, że językowoświadomościowa albo - jak kto woli - klasyczna koncepcja prawdy jest w stanie uchwycić z nich tylko tyle: zakomunikowanie pewnego rozpoznania). Miały one raczej na celu podważenie reguł dyskursu władzy, a raczej samej istniejącej wówczas struktury relacji władzy. Te wypowiedzi - te prawdy, ale w określony sposób ustrukturyzowane prawdy funkcjonowały raczej jako pewne wydarzenia, które nie mieściły się w ramach panującego porządku, zaburzały status quo (nieco dalej omówię tę zdarzeniowość na konkretnym przykładzie).

Ponadto dla prawidłowego uchwycenia funkcji tej mowy ważne jest zrozumienie, że wiązała się ona ze stałym zagrożeniem. Jan Sowa z pewnością ma rację, gdy - wskazując na osłabienie bloku radzieckiego (spowodowane zapaścią ekonomiczną lat siedemdziesiątych dwudziestego wieku) - stwierdza, że szanse na pacyfikację strajku były niewielkie (Sowa 2015, 131, 137-138). Nie należy jednak zapominać, że robotnicy nie posiadali tej „makrohistorycznej” perspektywy. Musieli natomiast mierzyć się z licznymi lokalnymi zagrożeniami: nie bez powodu rozstawiono straże, które miały uniemożliwić przedostanie się na teren Stoczni agentom służb bezpieczeństwa. Władze rozważały zresztą desant na Stocznię - o czym dowiedziano się, podsłuchując milicję (wspomina o tym Anna Walentynowicz, Gdańsk - Sierpień 1980, 9). Nie można również zapominać, że w sierpniu 1980 roku strajkujący dysponowali bardzo szczegółową wiedzą na temat zatrzymań i brutalnych pobić pomagających im kurierów. Rolę odegrała także żywa pamięć o Grudniu '70, kiedy to protesty robotników i robotnic zostały krwawo stłumione przez milicję i wojsko. Warto również wziąć pod uwage - jak czyni to Anna Machcewicz - że poczucie zagrożenia 
rodzą nie tylko działania militarne, ale także możliwość opustoszenia półek w sklepach, gigantyczne kolejki i spadek wartości pieniądza (Machcewicz 2015, 363).

Szczerość, nieuprzywilejowana pozycja, zdarzeniowy charakter wypowiedzi oraz stałe zagrożenie wskazują, że mowa członków Prezydium MKS (mowa strajkujących robotników w ogóle) posiada wszystkie cechy właściwe parezji. Niebagatelne znaczenie ma ponadto ich robotniczy status! - warto w tym miejscu na chwilę powrócić do Foucaulta i jego studiów nad antykiem. Choć, śledząc niemal tysiącletnią historię pojęcia parrēsia, wskazuje on na szereg przesunięć i modyfikacji związanych z jego użyciem, to jednak na niezwykle znaczący aspekt natrafia już w najstarszych źródłach. W tragedii Orestes Eurypidesa pojawiaja się cztery postaci mówców, ale tylko jednej z nich zostaje przypisana parezja. Ów bohater dramatu cechuje się trzema tradycyjnymi cnotami (odwaga, rozwagą oraz etyczną jakością) zapewniającymi istnienie prawdziwej i dobrej parezji, obok nich pojawia się jednak czwarty element, będący społeczno-polityczną charakterystyka. Mężczyzna, któremu przysługuje miano parezjasty, nie jest kimś, kto spędza cały swój czas na agorze, wdając się w niekończące się dyskusje - nie jest wprawnym mówca, retorem. Wprost przeciwnie, jest on kimś, kto pracuje własnymi rękami, jest autourgos - nie tyle sługa czy pracownikiem rolnym, co drobnym rolnikiem, który kładzie swe dłonie na pługu - przemawiającym przed Zgromadzeniem tylko wówczas, gdy zagrożone są sprawy polis (Foucault 2010a, 166-167). Dynasteia, polityczna gra, której niezbędnym elementem jest parezja, powierzona powinna być zatem nie tym, którzy całe dnie spędzają na agora, lecz tym, którzy związani sa z gé (dosłownie: uprawianą ziemia, jednak warto uchwycić tu bardziej ogólny sens, jakim jest przestrzeń produktywnej pracy).

Prostym przeciwieństwem werydykcji robotniczej jest postępowanie przedstawicieli rządu (Jagielskiego, Gniecha i innych). Przede wszystkim nagminnie stosowali oni kłamstwo $\mathrm{i}$ to często w bardzo bezczelnej postaci. Za przykład niech posłuży sytuacja blokady telefonicznej Gdańska: gdy strajkujący domagali się przywrócenia połączeń, członek komisji rządowej, Zbigniew Zieliński stwierdził, że nie jest to żadna blokada, ale efekt traby powietrznej, która dzień wcześniej przeszła nad Warszawa (Gdańsk Sierpień '80. Rozmowy, 258259). Przy tym opisał efekty owej wichury z niezwykłym bogactwem szczegółów. Tyle że połączenia telefoniczne nie były zerwane poprzedniego dnia, ale od dziewięciu dni, a media nie podały żadnej informacji o trąbie powietrznej. Robotnicy szybko przywołali te fakty, jak również ten, że telefon w biurze dyrektora Stoczni działał przez cały czas, i obnażyli tym samym kłamstwo Zielińskiego.

Inną taktyką przedstawicieli rządu było coś, co należałoby nazwać werydykcją instytucjonalno-jurydyczną. Pragnę nieco dłużej zatrzymać się przy konkretnym przykładzie. Dnia 28 sierpnia 1980 roku, w czasie negocjacji MKS-u z przedstawicielami rządu, Henryka Krzywonos opowiadała o nieuczciwym potraktowaniu jednego z robotników. 
[...] 24.08.80 roku Janusz Skorek, pracownik Stoczni Gdańskiej im. Lenina, został zatrzymany w Moragu, województwo olsztyńskie, osadzony w areszcie na 48 godzin i skonfiskowano mu sumę 10.978 zł, pochodzącą ze społecznej składki na pomnik Poległych Stoczniowców. Władze MO spytały go, dlaczego nie stawia innych [lub „im ich”, nagranie niewyraźne - przyp. CR] pomników. Nadmieniam, że wszystkie podstawowe... przedstawione przeze mnie fakty mogę udokumentować oraz [że] świadek jest na miejscu (Gdańsk Sierpień '80. Rozmony, 342, transkrypcja nieznacznie zmodyfikowana).

Wbrew zapewnieniom strajkującym i osobom wspomagającym strajk nie zostało zapewnione bezpieczeństwo. Na to wicepremier Jagielski odpowiada:

No cóż, pani mnie stawia pytanie. Co ja mogę na to więcej odpowiedzieć, prawda? [...] Uważam, że powinniśmy konsekwentnie przestrzegać praworządności. Konsekwentnie stać na gruncie Konstytucji Polskiej Rzeczpospolitej Ludowej (cate zdanie bardzo mocno zaakcentowane). Jeżeli są fakty łamania praworządności, ludzie, którzy ją łamia, powinni być pociagani do odpowiedzialności... prawda. [...] Natomiast... natomiast jeżeli, powiedzmy, w tej płaszczyźnie będziemy prowadzili rozmowy, no to po prostu będziemy rozpatrywali tutaj każdy, proszę państwa, konkretny przykład. [...] Wobec tego można jeszcze, można jeszcze, że tak powiem, przytaczać i kilka innych przykładów, prawda. Ale skoncentrujemy uwage na konkretnych przykładach, a nie na sposobie rozwiązania sprawy (tamże, 342-343, transkrypcja zmodyfikowana).

Ten scenariusz powtarza się wielokrotnie: robotnicy i robotnice przywołują kolejne przypadki łamania obietnic lub działania niezgodnego $\mathrm{z}$ przepisami (bezprawnych zwolnień dyscyplinarnych, ustawionych procesów sądowych itp.). I za każdym razem Jagielski mówi, że on wierzy (w prawdziwość tych słów), że rozumie i że jest mu bardzo przykro, iż dzieją się takie rzeczy oraz że te sprawy raz jeszcze trzeba wyjaśnić, np. udać się do sądu wyższej instancji. Przy czym każdorazowo z przywołanych przypadków (faktów, prawd) stara się uczynić odosobnione zrządzenie losu, efekt jakiegoś niedopatrzenia albo czynnika ludzkiego; przykładowo członek strony rządowej, Zbigniew Zieliński stwierdza, że sędzia prowadzący proces był łobuzem i trzeba iść do innego sądu, przecież nie może być tak, że we 
wszystkich sądach siedzą „dranie i łobuzy” (tamże, s. 344). W którymś momencie, w odpowiedzi na kolejną tego typu uwagę Jagielskiego odzywa się Andrzej Gwiazda:

Panie premierze, myśmy się tutaj rzeczywiście wdali w szczegóły, ale dopiero na szczegółach widać, jak działa prawo materialne, a nie samo... sama litera. Praktyczne działanie tego prawa widać dopiero właśnie w drobnych szczegółach, w drobnych ludzkich krzywdach. [...] Panie premierze, nie jest naszą intencją, żeby pan premier znał wszystkie drobiazgowe, prawda, przekroczenia i je... i udzielał na to odpowiedzi. Ale jest naszą intencją, żeby z tych szczegółów wyrósł jakiś obraz rzeczywistości panującej tutaj, na poziomie szarego człowieka (tamże, 345, transkrypcja zmodyfikowana).

Takie sytuacje ujawniają nie tylko charakter rządowej werydykcji, polegającej na interpretacji przypadku błędnego działania prawa jako jedynie usterki spowodowanej czynnikiem ludzkim. Przede wszystkim sa przykładami zdarzeniowego charakteru parezji. Rządowi zależy na tym, aby za wszelką cenę utrzymać struktury w istniejącej postaci, jedynie wymieniając ich elementy („zawartość przegródek”) lub przeprowadzając reformy mające zapewnić jeszcze większą stabilizację tych struktur. Zaś wszystkie specyficzne sytuacje rząd stara się, mimo wszystko, wpisać w owe już istniejące struktury, pokazując, że np. błędny wyrok sądu może być naprawiony poprzez odwołanie do sądu wyższej instancji lub dostarczenie nowych dowodów i ponowne rozpatrzenie sprawy. Tę zachowawczość szczególnie wyraźnie widać na przykładzie trzeciego ze sformułowanych przez MKS postulatów, który dotyczył cenzury: po jego omówieniu przez członka Prezydium MKS Jagielski stwierdza, że to, o co proszą strajkujący, już znajduje się w Konstytucji. Jeszcze lepszym przykładem jest wypowiedź Edwarda Gierka z 16 sierpnia 1980 roku, z posiedzenia Biura Politycznego KC PZPR. Ze względu na niejawny charakter tego spotkania możemy uznać, że mówił on do swoich towarzyszy szczerze i wprost:

Proponuję, aby zbyt długo nie dyskutować, w związku z tym, że sytuacja w Gdańsku jest nadal niejasna. Znajdziemy czas na dyskusję, gdy się uspokoi. Sam mam wiele przemyśleń. Trzeba m.in. podjąć problem związków zawodowych, ustawodawstwa pracy itd. Strajk stał się oczywistościa, ale zjawisko to musi się mieścić w istniejących strukturach, musi go poprzedzać jakieś działanie, rozmowy 
uprzedzające. W dotychczasowych przepisach konieczne sa poprawki [podkr. - CR]

(PZPR a „Solidarnośc" 1980-1981: tajne dokumenty Biura Politycznego, 92)9.

Przeciwnie funkcjonują wypowiedzi robotników i robotnic: mnożone przez nich przykłady maja na celu rozbicie zastanego porządku, wymuszenie zmiany samej struktury (a nie jedynie jakichś jej elementów). Rzecz nie w tym, by zastąpić nieuczciwego sędziego uczciwym, ale w tym, by zmodyfikować same stosunki społeczne.

I jeśli chodzi o techniki stosowane przez rządzących, to taka retoryka, czy może lepiej: takie odwoływanie się do istniejącej struktury, jest ważniejsze. Nie chodzi o to, żeby powiedzieć „władza zawsze kłamie” albo „rządzący muszą czasem kłamać, aby zachować porządek". To fakt, rządzący kłamia, ale takie stwierdzenia są mało interesujące z punktu widzenia mechaniki władzy. O wiele ciekawsze i płodniejsze naukowo jest przyjrzenie się sposobowi, w jaki rządzący mówia prawdę. Bo robią oni to często, oni rządzą za pomocą prawdy. Jedna z podstawowych słabości większości analiz dotyczących polityki tak wewnętrznej, jak i zewnętrznej - PRL-u polega na przyznawaniu nadmiernej wagi kłamstwu. Nie zaprzeczam, że było ono powszechną praktyką wśród członków Partii, że stało się niejako ich druga naturą (np. Goodwyn 1992, 68-70). Jednak stosunek badaczy do kłamstwa przesłania im widok na cały szereg innych technik rządzenia, opierających się właśnie na prawdzie. Tyle że jest to określony sposób mówienia prawdy: odwołujący się do reguł istniejących instytucji, do ich regularności, do transcendentnego, bezosobowego porządku prawa. Władza mówi prawdę niejako w nie-swoim imieniu, mówi ją bezosobowo (,takie sa przepisy”). Przeciwnie parezjasta - mówi ją w swoim imieniu (to jemu grożą reperkusje), a jego wypowiedź ma charakter zdarzeniowy, wymykający się prawidłowościom obowiązującego dyskursu i zastanych relacji władzy.

9 Wydaje się, że Jagielski rozwija stanowisko Gierka, gdy 28 sierpnia, pod koniec negocjacji, stwierdza, że jeśli jest taka potrzeba, to trzeba zmodyfikować przepisy ,zarówno w problematyce dotyczącej pracy, zarówno w problematyce bezpieczeństwa pracy, zarówno w problematyce strajków, prawda, i bezpieczeństwa osób strajkujących, co się wiąże - że tak powiem - z koncepcją ustawy, prawda, która by tę sprawę regulował[a], bo na całym świecie problem strajku jest prawnie uregulowany (w ostatniej çeśsi zdania Jagielski mocno akcentuje każde poszrzególne stowo). Jest wyraźnie powiedziane: kiedy, jak, w jakim trybie, w jaki sposób, z jakimi, że tak powiem, obustronnymi konsekwencjami” (Gdańsk Sierpień '80. Rozmowy, 344-345, transkrypcja zmodyfikowana). 


\title{
Zła parezja
}

Pomiędzy parezją z jednej a kłamstwem oraz werydykcją jurydyczną z drugiej strony istnieje dosyć prosta opozycja. Ale również parezja jako taka nie jest wolna od słabości. Foucault wskazuje na występowanie czegoś, co określa on mianem złej parezji (oczywiście nie chodzi tu o zło moralne, ,zła” znaczy w tym wypadku raczej tyle, co nieskuteczna, nieudana albo nieadekwatna do nakazu chwili). Towarzyszące parezji nieusuwalne zagrożenie sprawia, że niektórzy nie mają odwagi zaryzykować wypowiedzenia niewygodnej prawdy wobec tych, którzy sprawują rządy. Zamiast tego wykorzystuja pozycję mówiącego do przypodobania się rządzącym (Foucault 2010a, 180-183). Dzięki nagraniom magnetofonowym z Sierpnia '80 pozostał nam co najmniej jeden przykład pochlebstwa. Późnym wieczorem 21 sierpnia w sali posiedzeń MKS-u do mikrofonu podszedł Ireneusz Leśniak, zastępca kierownika wydziału kadr. Przeczytał on długie oświadczenie (które sam określił jako historyczne), kończące się następującym apelem do ówczesnego I sekretarza KC PZPR:

\begin{abstract}
Dlatego też błagam najpokorniej w imieniu własnym i wszystkich Polaków was, towarzyszu Edwardzie Gierek, o przybycie tutaj do nas i jak najrychlejsze podjęcie rozmów, gdyż tylko was darzymy pełnym zaufaniem. Ponieważ obok naszego papieża, Jana Pawła II, jesteście jedynym autorytetem zdolnym wyprowadzić nasz kraj z obecnego impasu, ponieważ znacie życie robotnika i rewolucjonisty znacznie lepiej niż ktokolwiek inny. Buntujemy się nie przeciwko wam, partii czy ustrojowi, lecz przeciwko metodom i sposobom realizacji głoszonych przez was idei (Gdańsk Sierpień '80. Ro:mony, 189, transkrypcja nieznacznie zmodyfikowana) ${ }^{10}$.
\end{abstract}

Charakterystyczne w wypowiedzi Leśniaka były paternalistyczny ton nieustannych nalegań o ciszę oraz zapewnienia, że nie zależy mu na poklasku (przy czym w odpowiednich momentach swojej przemowy robił dłuższe pauzy). Warto zaznaczyć, że przywołany odczyt nie ograniczał się wyłącznie do pochwały władzy (a raczej: samego Gierka), ale pozytywnie wartościował również postawę strajkujących. Imitacja parezji nie polegała tu na kłamstwie,

10 Chociaż Anna Walentynowicz oskarżyła wówczas Leśniaka o kłamstwo - „Bardzo ładnie mówił pan Leśniak, ale trudno uwierzyć, kiedy mówi prawdę" (Gdańsk Sierpień '80. Rozmowy, 190) - to jednak wydaje się, że sytuacje trafniej zdiagnozował Stanisław Esden-Tempski z Koła Młodych Związku Literatów Polskich. Stwierdził on: „Proszę państwa, ja nie sądzę, żeby pan Leśniak był prowokatorem. Wydaje mi się, że jest to po prostu człowiek, który zabrnął w ślepą uliczkę działalności partyjnej, a widząc jak szczery, jak wielki jest ruch, którego reprezentanci siedzą na sali, wreszcie poczuł, że należałoby do tego ruchu przystapić i chciał... chciał się stać na jeden wieczór bohaterem tego wieczoru” (tamże, 194). 
lecz na wyprodukowaniu dyskursu konformistycznego, pozbawionego zdarzeniowego charakteru.

Wydaje mi się jednak, że obok pochlebstwa można wskazać na jeszcze jeden, inny rodzaj złej parezji, którego Michel Foucault nie uwzględnił w swych rozważaniach. Mam na myśli pewne głosy krytyczne wobec Prezydium MKS-u, nasilające się zwłaszcza w ostatnich dniach negocjacji. Z jednej strony, głosy takie podnosiła grupa przedstawicieli Konfederacji Polski Niepodległej (KPN), wzmocniona później o aktywistów Ruchu Młodej Polski (RMP). Obie te organizacje opowiadały się za suwerenną Rzeczpospolita Polska, wolna od sowieckiej dominacji i władzy PZPR-u. O tyle umieszczenie w pierwszym postulacie sformułowania o „przewodniej roli PZPR w państwie” było dla nich obrazą świętości. Uznali oni pierwszy postulat za zdradę i usiłowali przekonać do tego poglądu każdego napotkanego robotnika i członka MKS-u. Chociaż niechęć do PZPR-u była całkowicie zrozumiała, to jednak agitacja na rzecz zakwestionowania kierowniczej roli Partii była błędem strategicznym wynikającym z niewiedzy o „mechanizmach robotniczej samoorganizacji”" (Goodwyn 1992, 378). Chociaż reprezentował niemal 600 zakładów pracy, to ten MKS wciąż działał tylko na Wybrzeżu i nie był wówczas w stanie doprowadzić do powstania strajku ogólnokrajowego - jedynego, który miał szansę obalić rządy PZPR-u. Andrzej Gwiazda, po latach, w następujących słowach komentował tę sytuację:

Ryzyko, że zamiast Komisji Rządowej przyjadą czołgi, było bardzo duże, ale tego „przyziemnego” argumentu „prawdziwi niepodległościowcy” nie chcą słuchać. Natomiast wydaje im się całkiem naturalne, że niepodległość można otrzymać z rąk okupanta, że można o nią zabiegać u narzuconej władzy, że może być przedmiotem negocjacji (Gwiazdozbiór w „Solidarności”, 146).

Warto również zaznaczyć, że choć KPN działał wówczas już od jedenastu miesięcy, to nie udało mu się skoordynować działań na miarę MKS-u ani nawet zyskać masowego poparcia. Z drugiej strony, wzbudzony przez KPN i RMP niepokój udzielił się jednak wielu osobom, między innymi Konradowi Bielińskiemu i Mariuszowi Wilkowi, odpowiedzialnym za publikację strajkowego biuletynu. Wraz z należącym do Komitetu Obrony Robotników prawnikiem Jackiem Taylorem i małą grupa delegatów robotniczych „zaczęli szkicować statut, dzięki któremu MKS mógłby mocą jednostronnej decyzji przekształcić się w samorządny związek zawodowy" (Goodwyn 1992, 379). Tak jakby ten prosty trick mógł zastapić ryzykowne i prowadzone przez wiele dni negocjacje. Efektem mógł być co najwyżej nielegalny ruch opozycyjny, zrzeszający w najlepszym wypadku tysiące (tak jak to było w przypadku innych tego typu organizacji) - niemal oczywiste było zaś, że uznany oficjalnie związek zawodowy przyciąnnie o wiele więcej osób (w szczytowym momencie było to 
10 milionów). Samo przedsięwzięcie Bielińskiego i Wilka miało ponadto charakter votum nieufności wobec zespołu doradców MKS-u (to od nich pochodziło sformułowanie o „przewodniej roli PZPR w państwie”). Sam Bieliński wygłosił namiętną mowę podczas nadzwyczajnego zebrania prezydium 29 sierpnia:

\begin{abstract}
Bieliński przypomniał wszystkim o swoich zasługach dla biuletynu strajkowego i o tym, że dotychczas grzecznie milczał w sprawie strategii. Ale ponieważ obecnie widać, że negocjacje „nie przynoszą rezultatów” [warto pamiętać, że wiadomość o zgodzie rządu na najważniejszy, pierwszy postulat dotarła do Stoczni już następnego dnia rano - przyp. CR], zdecydował się podjąć akcję, dzięki której strajkujący nie wyjdą ze Stoczni „z pustymi rękami”. Bieliński skrytykował zespół doradców robotniczych za spotkanie $\mathrm{z}$ ekspertami rządowymi za zamkniętymi drzwiami i za „wysuwanie się przed robotników”, po czym oświadczył, że nadszedł czas, aby opozycja określiła się jako szereg „ruchów społecznych” wiernych „strategii aktywności” (tamże, 379-380).
\end{abstract}

Bieliński nie tylko zdawał się zapomnieć, że doradcy MKS-u byli tylko tym: doradcami, i nie mogli podejmować, nawet za zamkniętymi drzwiami, żadnych decyzji. Przede wszystkim jednak zachowywał się tak, jakby miał lepsze od innych predyspozycje do kierowania ruchem robotniczym. Chociaż był doświadczonym działaczem ruchów studenckich i członkiem KOR-u, to jednak pod względem umiejętności działania w ruchu robotniczym nie mógł się równać z Wałęsa czy Gwiazda (niepokojąca była również jego arogancja, wyrażająca się w uznaniu za wielką zasługę własnej działalności wydawniczej).

Kolejne głosy krytyki, pochodzące od „samozwańczych ekspertów od wielkiej polityki" (tamże, 382, podkr. - CR), zaczęły pojawiać się 30 sierpnia (już po decyzji rządu i świętowaniu zwycięstwa przez robotników) na sali zebrań MKS-u. Przede wszystkim oskarżano Prezydium o zdradę (zaniepokojenie wzbudził fakt, że Jagielski tuż przed wyjazdem do Warszawy pochwalił Prezydium za stanowisko w sprawie ,ideologicznego i politycznego profilu” mających powstać związków zawodowych). W moim przekonaniu oskarżenia o zdradę były - podobnie jak działania KPN-u, RMP oraz młodych KOR-owców - przejawem czegoś, co również można by określić mianem złej parezji, choć odmiennej od pochlebstwa. $Z$ pewnościa przedstawiciele wspomnianych grup szczerze mówili o swojej nienawiści do PZPR-u i z pewnością ich poglądy podzielało wielu Polaków. Z tą szczerością wiązały się jednak dwa niezwykle istotne problemy. O pierwszym już wspominałem: to zupełnie nieadekwatne rozpoznanie sytuacji strategicznej - MKS, nawet gdyby chciał, nie miał środków do obalenia rządu, miał natomiast środki do wymuszenia na nim zalegalizowania niezależnych, samorządnych związków zawodowych. Po drugie, szczera 
(prawdziwa) mowa KPN-owców, Bielińskiego i innych była skierowana do Prezydium, a przede wszystkim do „szeregowych” robotników ze Stoczni oraz delegatów innych zakładów - nie była natomiast skierowana do przedstawicieli rządu. Zupełnie wyeliminowany został tu aspekt ryzyka i związanej z nim odwagi - robotnicy, do których przemawiano, choć mogli zareagować gniewnie, nie stanowili większego zagrożenia (wspomnianego wcześniej Ireneusza Leśniaka po prostu wyprowadzono poza teren Stoczni). Co więcej, to odwrócenie kierunku powoduje, że mówiący wyodrębnia się spośród rządzonych i zajmuje pozycję podobną do rządzącego, jego mówienie prawdy przybiera zaś postać propagandy (raczej zdobywania elektoratu lub poklasku niż zaburzania status quo).

Wspólną cechą obu rodzajów złej parezji jest próba wyeliminowania związanego z nią zagrożenia, usiłowanie zapewnienia sobie przez mówcę bezpieczeństwa. Odbywa się to na dwa sposoby: albo mówi się wobec władzy, ale rezygnuje ze zdarzeniowego tzn. rozmontowującego zastany dyskurs - charakteru wypowiedzi (to przypadek pochlebstwa), albo zachowuje się zdarzeniowy charakter wypowiedzi (choć trzeba zaznaczyć nad wyraz wątpliwą skuteczność tej „zdarzeniowości”), ale nie kieruje jej do władzy (to przypadek „samozwańczych doradców”). Obok tego istnieja jeszcze dwa powody wyłonienia się dyskursu, który imituje parezję. Po pierwsze, o czym była już mowa przy okazji pochlebstwa, to mówienie ma postać konformistyczna, reprezentuje dominująca opinię (w jednym przypadku rządzących, w drugim - powszechną wśród robotników niechęć do PZPR-u). „Zły parezjasta” mówi tylko o tyle, o ile jego słowa zgodne są z mniemaniami innych, w ten sposób unika ponoszenia konsekwencji swojej wypowiedzi. Po drugie, owo wypaczone mówienie prawdy bierze się z faktu, że może przemawiać ktokolwiek. To moment newralgiczny dla zrozumienia sformułowanej przez Foucaulta koncepcji. W antycznych Atenach możliwość przemawiania wynikała początkowo z pochodzenia (przynależności do starego rodu szlacheckiego, zwłaszcza rodu związanego z uprawą ziemi) oraz tradycji. Wyłonienie się złej parezji wynika - zdaniem takich postaci jak Eurypides albo Izokrates z tego, że wymóg ten zanika, a prawo do przemawiania staje się prawem konstytucjonalnym. Odtąd faktycznie będzie przemawiał ktokolwiek i tym samym ktokolwiek będzie miał wpływ (na rządy), choćby ten, który dopiero od niedawna jest obywatelem (Foucault 2010a, 182). Mogłoby się wydawać, że Foucault - idąc za starożytnymi - krytykuje tu bardziej demokratyczne rozwiązanie w imię jakiegoś elitaryzmu. Ten błąd interpretacyjny zostanie jednak sprostowany, jeśli tylko weźmiemy pod uwagę wprowadzone wcześniej rozróżnienie pomiędzy politeia a dynasteia. Zła parezja wynika z zapoznania dziedziny właściwej gry politycznej (czyli warunków de facto mówienia prawdy) i oparcia wszelkiej polityki na rozstrzygnięciach konstytucjonalnych (na warunkach de iure). W efekcie uznaje się, że o mówieniu prawdy rozstrzyga prawo, gdy w istocie decydujące znaczenie ma charakter tych, którzy grają w grę polityczna, ich etos. Choć w wadze, jaka Eurypides czy Izokrates przyznaja 
pochodzeniu i tradycji, łatwo doszukać się rysów konserwatywnych, to Foucault - w typowy dla siebie sposób - wyprowadza z ich rozważań wnioski kontrintuicyjne. Przede wszystkim chodzi o uwolnienie teorii i praktyki politycznej od ich dyskursywno-jurydycznej formy i zakorzenienie ich w etyce, czyli w sposobach upodmiotowiania się jednostek grających w grę polityczną. (Stąd właśnie podwójna, etyczno-polityczna natura parezji, o czym wspominałem w paragrafie „Werydykcja”).

Wskazanie na ten styk etyki i polityki to jednak tylko połowa problemu. Druga połowa dotyczy prawidłowego określenie relacji pomiędzy tymi dwiema dziedzinami. Chciałbym raz jeszcze odwołać się do nagrań, które pozostały po Sierpniu '80. Odsłuchując jedno z nich, zarejestrowane 30 sierpnia 1980 roku, trafiłem na następująca wypowiedź mężczyzny (którego nazwiska nie udało mi się zidentyfikować):

\begin{abstract}
Prosze państwa! Dwa i pół tygodnia żeśmy strajkowali. Dwa i pół tygodnia [stały] stocznie. Trzeba było tych dwóch i pół tygodnia, by rząd zrozumiał naszą siłę. I teraz, w momencie kiedy czuja przez nami respekt, bo cała Polska jest za nami, my podpisujemy i mamy tutaj usankcjonować punkty, przy których ten najważniejszy punkt, [opatrzony jest] klauzula, że są wolne związki zawodowe z kierowniczą rola partii. Jakie to są wolne? Jakie to są niezależne?
\end{abstract}

Andrzej Gwiazda odpowiada na to:

\begin{abstract}
Proszę państwa! Jakie będa związki zawodowe, zadecyduja członkowie. Ja stoję na tej zasadzie. (oklaski) Jeśli będziecie chcieli, żeby były naprawdę wolne, to będa, niezależnie od tych paragrafów, które podpiszemy. Jeśli nie będziecie przy tym obstawać — nie będą. Niezależnie od deklaracji (Gdańsk Sierpień '80, 405).
\end{abstract}

Przywołuje ten komentarz Gwiazdy z tego względu, że potwierdza on - w moim przekonaniu - to, o czym pisałem wcześniej. Celem strajku tylko wtórnie była zmiana przepisów, zmiana prawodawstwa; rzeczywista stawka była tu etyczna, tzn. dotyczyła sposobu życia robotników.

Zależność pomiędzy etyką i polityką może być dwojaka. Jeśli pierwsze są rozstrzygnięcia natury prawno-politycznej, to wówczas nasze praktyki siebie zostają im podporządkowane, a etyka staje się moralnościa. Edward Abramowski całkiem słusznie nazywał taki twór etyką policyjną (Abramowski 1924, 275). Politeia, prawo i konstytucja są tutaj uznane za najważniejsze, życie ma im tylko podlegać - a dbać o to maja odpowiedni nadzorcy. Właściwa polityka, tzn. dynasteia zostaje tu zepchnięta w cień: nie chodzi o to, że nie 
da się jej wskazać, lecz o to, że nie potrafi się o niej myśleć i problematyzować jej inaczej, jak tylko jako walki o prawa i przywileje. Inaczej jest w drugim przypadku, gdy pierwszeństwo przyznaje się dynasteia, tę zaś opiera na etyce. Wówczas to dopiero porządek instytucjonalnoprawny faktycznie jest konstytuowany „od dołu” (można by powiedzieć: bez transcendentnych inicjatorów), poprzez rzeczywistą grę polityczną. Można by powiedzieć: musimy inaczej żyć, by mieć inne prawa, a nie zmienić prawa, by inaczej żyć. W istocie jednak nie o prawa tu chodzi, ale właśnie o samo kształtowanie egzystencji. Być może dynasteia należałoby ostatecznie rozumieć jako politykę, w której stawką jest sposób prowadzenia życia.

\section{Atrofia sierpniowej demokracji}

Warto na koniec rozważyć dwa podstawowe warunki genezy obu typów owej „złej parezji”. Wagę pierwszego z nich wielokrotnie - choć w nieco innym kontekście - podkreśla amerykański badacz Lawrence Goodwyn w książce Jak to zrobiliście? Mam tu na myśli wyłączenie stoczniowego radiowęzła. Niezbędne jest krótkie opisanie roli tego zespołu urządzeń. Począwszy od pierwszego spotkania z dyrekcją Stoczni, które miało miejsce 14 sierpnia 1980 roku, na długo przed przyjazdem delegacji rządowej, strajkujący robotnicy nagłaśniali wszystkie prowadzone przez siebie negocjacje za pomocą radiowęzła. Dzięki temu prowadzone rozmowy mogli usłyszeń wszyscy robotnicy i wszystkie robotnice przebywające na terenie Stoczni. A także w innych trójmiejskich zakładach, które - jak choćby „Elmor” podłączyły swoje radiowęzły do stoczniowego. Umożliwiało to strajkującym swoistą kontrolę negocjacji pomiędzy ich przedstawicielami a stroną rządową. Jeśli tylko w rozmowach pojawiały się propozycje nieakceptowalne dla robotników i robotnic, ci natychmiastowo wyrażali swój sprzeciw. Radiowęzeł zapewniał również sytuację przejrzystości w kontakcie z Partią, wobec której strajkujący żywili głęboką nieufność. Przede wszystkim jednak nagłośnienie hamowało możliwość wydzielenia się spośród robotników i robotnic jakiejś grupy przywódczej, która przejęłaby na wyłączność kompetencje decyzyjne. Strajk nie miał głowy, którą można by ukręcić lub - jak kto woli - był wielogłową hydra, przeciw której rząd nie potrafił walczyć. Wyraźnie wskazują na to wciąż powtarzające się zabiegi członków Partii, by przenieść negocjacje poza Stocznię lub ograniczyć je do rozmów w wąskim gronie, za zamkniętymi drzwiami (i - oczywiście - przy wyłączonych mikrofonach). Z drugiej strony, robotnicy i robotnice doskonale zdawali sobie sprawę z tego, że nie mogą dopuścić do takiej sytuacji i nie zgadzali się na owe propozycje. Ponadto odmówili jakichkolwiek negocjacji z rządem, dopóki ten nie przywróci połączeń telefonicznych z resztą kraju. Robotnicy 
i robotnice ostro walczyli też o ochronę osób pomagających przy strajku, zwłaszcza kurierów. Wszystkie te świadome zabiegi miały na celu zapewnienie sobie poziomej komunikacji, szybkiego obiegu informacji oraz jawności wszelkich działań.

Nadawały one robotniczemu ruchowi postać demokratyczną - jawność i pozioma komunikacja pomiędzy strajkującymi likwidowała wszelkie hierarchie. Członkowie Prezydium MKS-u wielokrotnie podkreślali, że jedynie pośredniczą w rozmowach i jeżeli Jagielski lub ktoś inny pragnie coś osiagnać, to ma zwracać się do robotników i robotnic właśnie. W nieco innym kontekście zgrabnie to ujął Wałęsa:

Faktem jest, że nawet jak tam jest nas osiemnastu i ekspertów trzech, czterech, to n[ie]... i po tamtej stronie ze dwudziestu, więc byśmy się naprawdę nie dogadali; bo ten ma to, ten to. My mamy konkretnie to, co chcemy, wszyscy mamy jedną listę i mówimy: ten punkt w konstytucji poprawić, ten punkt w kodeksie wykreślić i tak dalej, i tak dalej... Więc to oni tam uzgodnia, przyjada, pokażą (każde z træẹch stón przeciagnięte) nam jak to wygląda, my poczytamy - jeśli dobrze, no to okej, a jeśli nie, to w dalszym ciagu to samo [transkr. i podkr. - CR $]^{11}$.

Ze względu na konsekwencje związane z polityczną kategorią reprezentacji uważam, że nieprawidłowe jest stwierdzenie, iż Prezydium MKS reprezentowało robotników. Prezydium MKS powołano jedynie jako instrument ${ }^{12}$ : tysiące robotników i robotnic nie mogły mówić równocześnie, toteż posłużono się kilkoma osobami, które niejako „przenosiły” głos pozostałych. A dzięki nagłaśnianiu negocjacji przez radiowęzeł strajkujący mogli na bieżąco reagować na przebieg rozmów - i robili to, wyrażając swoje niezadowolenie lub poparcie. O tyle należałoby powiedzieć, że robotników i robotnic nikt nie reprezentował, ale że prezentowali się oni sami - na tym właśnie opierała się prawdziwie demokratyczna struktura strajku. Jak pisze Goodwyn: „[...] wierzono (i na tym polegała mądrość ruchu), że informacja stanowi gwarancję dalszej solidarności” (Goodwyn 1992, 82).

11 Wedle Drzycimskiego jest to wypowiedź z dnia 26 sierpnia 1980 roku (Gdańsk Sierpień '80. Rozmowy, 301-302); u Chojeckiego (Gdańsk - Sierpień 1980) zupełnie brak tego fragmentu; natomiast udostępniony mi przez ECS plik z nagraniem opatrzony był datą 21 sierpnia 1980 roku. Opierając się na wspomnieniach Giełżyńskiego (Giełżyński, Stefański 1981, 137), można jednak uznać, że rację ma Drzycimski. Przyjmując tę właśnie wersję, należy założyć, że Wałęsa próbował tymi słowami przekonać strajkujących do akceptacji posiedzeń małych, działających „za zamkniętymi drzwiami” grup roboczych, tzw. trójek. Owe trójki od początku wzbudzały wielką nieufność robotników, co - jak pokażę dalej - nie było bez znaczenia. Choć poparcie grup roboczych było jednym ze strategicznych błędów Wałęsy, to jednak jego wypowiedź - o ile abstrahujemy od jej kontekstu - dobrze ilustruje pozycje ,„przedstawicieli” robotników i robotnic.

12 W nieco innej sytuacji dobrze to ujął dawny sekretarz generalny CFDT: „M. Foucault: W jakim stosunku związek pozostaje wobec klasy? Czy jest to relacja reprezentacji (on ja reprezentuje)? Instrumentalna (ona posługuje się nim jak bronia)? Dynamizująca (on ją uświadamia i podsuwa formy działania)? E. Maire: Związek zawodowy jest instrumentem pozwalającym klasie określić swój projekt i działać na jego podstawie. Jest on jednocześnie środkiem refleksji, określania zadań i działania tej klasy” (Foucault 2013b, 380). 
Pierwsze i poważne odstępstwo od zasady jawności miało miejsce 26 sierpnia: nie nagłośniono wówczas rozmów prowadzonych przez grupę roboczą (składającą się z trzech członków Prezydium MKS-u, trzech ekspertów, trzech przedstawicieli rządu i trzech ich doradców - stąd potoczne określenie owych grup jako „trójek”). Dziennikarz Wojciech Giełżyński, który przebywał wówczas w Stoczni, wspomina, że ta dyskrecja od razu wzbudziła niepokój robotników (Giełżyński, Stefański 1981, 137). To podczas tych ustronnych rozmów pojawiły się pierwsze sugestie o przeformułowaniu pierwszego postulatu. Oczywiste jest, że zależało na tym stronie rządowej; warto jednak zaznaczyć, że i część przedstawicieli inteligencji, doradzających robotnikom, nie wierzyła w przeforsowanie postulatu pierwszego w jego dotychczasowym kształcie. Próbowali oni dyskretnie przekonać MKS do zrezygnowania z niego i poprzestania na radykalnej przebudowie starych związków zawodowych (zaświadcza o tym jeden z obecnych: Kowalik 1983, 9). Mówiąc nieco dosadniej: przedstawiciele inteligencji chcieli ukrócić rewolucyjne zapędy strajkujących i nakłonić ich do postawy reformistycznej. W wyniku sprzeciwu robotników zrezygnowano z tego pomysłu. Zamiast tego postanowiono przeformułować pierwszy postulat $\mathrm{w}$ taki sposób, aby zawierał on wzmiankę o kierowniczej roli Partii w państwie (ale nie w społeczeństwie!). Było to bardzo dobre posunięcie taktyczne, związane jednak z pewnym poważnym błędem. Na wniosek Tadeusza Mazowieckiego zrezygnowano z publicznego odczytania tej zmiany (zrobiono to dopiero dwa dni później, jednak nie naprawiło to już sytuacji). Owa nieprzejrzystość wzbudziła wśród strajkujących niepokój. I to właśnie ten niepokój wykorzystali Bieliński czy agitatorzy z KPN-u, by podważyć wiarygodność Prezydium MKS-u (oraz przejać strajk dla własnej sprawy).

Druga - obok problemu radiowęzła - kwestia wiąże się z czymś, co można by określić mianem „przestrzeni parezjastycznej”. W moim przekonaniu strajk w Stoczni polegał m.in. na stworzeniu przestrzeni do mówienia wobec władzy czy raczej zmuszenia władzy do posłuchu, aby mogła być uruchamiana parezja. Jak wspomniałem wcześniej, parezjastyczna gra wymaga tego, aby istniała strona słuchająca - choć dominująca i zagrażająca, mogąca w każdej chwili przestać słuchać, to jednak do pewnego stopnia otwarta na mowę parezjasty. Banalnym będzie stwierdzenie, że rząd PRL-u (i nie tylko PRL-u) nie miał zwyczaju słuchać obywateli. Nawet jeśli czasem pozwalał studentom czy robotnikom wypowiedzieć swoje niepokoje czy wątpliwości, to nie traktował tych grup jako partnerów rozmowy. „Uciszyć ludzi, powstrzymać ich przed mówieniem i, przede wszystkim, kiedy mówią, zachowywać się tak, jakby nic nie powiedzieli" (Deleuze i Guattari 2015, 44) oto strategia rządzących. Zdobyczą Sierpnia '80 była nie tylko ilość zakładów, które przyłączyły się do Stoczni, ale może przede wszystkim wytrwałość robotników i robotnic w dążeniu do sprowadzenia na negocjacje jednego z najważniejszych urzędników państwowych i zmuszenia go do poważnego potraktowania tego, co mówią strajkujący. Potrzeba nie tylko 
szczerej i odważnej mowy, ale również przestrzeni dla niej. Stworzenie tej ostatniej było czymś, co nie tylko nie powiodło się KOR-owi, KPN-owi, Klubom Inteligencji Katolickiej czy innym ruchom opozycyjnym, ale nie powiodło się również w roku 1956 ani nawet podczas Grudnia '70 (być może to z tej perspektywy należy oceniać krwawy finał tamtych wydarzeń: strajkującym nie udało się wówczas zawiązać z rządzącymi „parezjastycznego paktu”, przez co możliwa była już tylko brutalna konfrontacja).

W tym miejscu sytuuje się również drugi mechanizm odpowiedzialny za uruchomienie w przedstawicielach środowisk opozycyjnych spoza Stoczni mechanizmu złej parezji. Wszyscy oni byli z zewnątrz, nie brali udziału w konstytuowaniu przestrzeni parezjastycznej i nie rozumieli podstawowych warunków jej genezy. A tymi były samoorganizacja, solidarność, zawziętość i przede wszystkim zaprzestanie pracy, nie zaś przywoływane niekiedy w trakcie negocjacji odwołania do konstytucji czy zgrabne formułki prawne. (Przy okazji warto zauważyć, że taki sposób postępowania przedstawicieli inteligencji pociagał za sobą ten sam typ mowy, który stosowała strona rządowa: werydykcję instytucjonalno-jurydyczna. Stąd, z jednej strony, „profesjonalne koleżeństwo” pomiędzy dwoma obozami akademików zasiadających w grupie roboczej, a z drugiej, nieufność robotników i robotnic również wobec tych intelektualistów, którzy stali po stronie strajkujących - zob.: Goodwyn 1992, 91-97).

\section{Zakończenie}

Zadanie, które postawiłem sobie w ramach niniejszego artykułu, polegało na odzyskaniu dla lewicy tzw. pierwszej „Solidarności” (a także późnego Foucaulta). Jak jednak pokazuje dyskusja, która rozgorzała po publikacji Innej Rzeczpospolitej Sowy, nie jest wcale oczywiste to, na czym takie odzyskiwanie polega. Rzecz nie w tym, że przedstawiciele polskiej lewicy znacząco różnią się między sobą w ocenie pierwszej „Solidarności” (inaczej wartościuja ją np. Gdula 2015, Siermiński 2015). W powyższym artykule ukazuję działania strajkujących oraz używanego przez nich Prezydium MKS w pozytywnym świetle; czy w ten sposób, wbrew ostrzeżeniom wspomnianych autorów, ignoruję fakt powszechnego w „Solidarności” - i to od samych jej początków - szowinizmu, nacjonalizmu i klerykalizmu? Bynajmniej. Nie zamierzam tym tekstem bronić tezy o jakichś złotych miesiącach (czy choćby tylko dniach) „Solidarności”, o jasnym i dobrym źródle, które następnie zostało zbrukane. Byłoby to jedynie kolejną, równie irytująca co wszystkie wcześniejsze, próbą wprowadzenia do historii pewnego rodzaju metafizyki (lub platonizmu, jak kto woli). Nie istnieje, nawet u zarania, żadna istota - ani dobra, ani zła, ani komunistyczna, ani nacjonalistyczna - „Solidarności” 
czy jakiegokolwiek innego zjawiska historycznego. Mamy do czynienia jedynie, i to lekcja, którą daje nam nieustannie nie tylko Foucault (aż dziw, że niektórym trzeba o tym przypominać), z heterogenicznymi wiązkami procesów, konstelacjami praktyk, mikro-polami bitew, na których ścierają się różnorodne siły. Niektóre z nich są siłami represji, inne siłami wyzysku, kolejne siłami urazy, jednak istnieją też siły współpracy, siły emancypacji i siły nie mylić ich z poprzednimi - użytku z wolności.

Odzyskać coś, to opowiedzieć starą historię raz jeszcze, wskazując jednak innych jej bohaterów, kładąc nacisk na inne wątki, kreśląc obrazy z innych punktów widzenia. Dzięki temu możliwe staje się inne wejrzenie w przeszłość - również własna; odmienne zrozumienie podejmowanych, również przez siebie, działań. A co za tym idzie: skorygowanie, udoskonalenie obecnych strategii. Odzyskać coś dla lewicy to szukać tego, co emancypacyjne, egalitarne itp. Aby było to możliwe, należy - by posłużyć się metafora - przeanalizować mieszaninę z użyciem innego (niż ten, który reaguje na ksenofobię czy szowinizm) wskaźnika chemicznego: dla Sowy było to m.in. pojęcie dobra wspólnego, dla mnie - Foucaultowskie pojęcie parezji. Pozwoliło mi ono wydobyć nie tylko emancypacyjny, solidarnościowy oraz egalitarny charakter mowy robotników - te były dostrzegalne również przy użyciu innych narzędzi teoretycznych. O wiele ważniejsze było ujawnienie tego, jak musi być skonstruowana wypowiedź, aby miała moc przełamywania dyskursu stosowanego przez rządzących. Ponieważ ci ostatni w sytuacjach konfliktowych posługują się werydykcją instytucjonalno-jurydyczną (tymczasowo wliczam w to również argumentacje ekonomiczna), rządzony lub rządzona - o ile usiłuje otworzyć sytuację, w jakiej się znajduje - nie może uprzywilejowywać języka tego samego rodzaju: języka reguł, praw, konstytucji. Nawet jeśli odwołuje się do tychże, to jedynie wtórnie; w pierwszej kolejności mówi bowiem o tym, co jednostkowe - nie indywidualne, prywatne, ale: wymykające się obowiązującym normom i zasadom, nietypowe, osobliwe. Jeśli przytacza jakiś zapis w konstytucji, to raczej po to, by opowiedzieć o jednostkowej krzywdzie. Z tej perspektywy dyskurs, jaki produkowali intelektualiści z KOR-u czy KIK-ów, właśnie dyskurs instytucjonalno-jurydyczny, okazuje się pozbawiony mocy otwierania sytuacji politycznej (być może należałoby ująć to bardziej dosadnie: okazuje się pozbawiony jakiejkolwiek mocy rewolucyjnej). Ostatecznie bowiem ten lub ta, która posługuje się parezja, nie uruchamia bezosobowego dyskursu transcendentnych reguł, ale zakorzenia mowę w sobie samym lub w sobie samej, w swych przeżyciach, w swej egzystencji, wreszcie w swej własnej odwadze, w swym etos, które sytuuje się poza wszelkimi kodeksami.

Z drugiej strony, zastosowanie pojęcia parezji do opisu sytuacji w Stoczni Gdańskiej im. Lenina pozwala lepiej zrozumieć zagrożenia, z jakimi musi mierzyć się ta praktyka. Większość badanych przez Foucaulta „układów parezjastycznych” była dwuelementowa: mówca stojący przed Zgromadzeniem, cynik zaczepiający mieszkańców miasta czy nauczyciel 
troski o siebie zwracający się do osoby, której pomaga. Jedynie omawiając przypadek doradcy Księcia lub też parezjasty stającego w obliczu tyrana, Foucault wprowadza strukturę trójelementowa - trzecim jej składnikiem jest dwór. Materiał, na którym pracuje, nie pozwala mu jednak wyprowadzić wszystkich konsekwencji z takiej sytuacji. W Stoczni również mamy do czynienia ze układem trzech pozycji: robotnicy-Prezydium MKS-strona rządowa. Parezjasta zajmuje tu pozycję środkowa, w taki jednak sposób, że zwraca się do strony rządowej, przekazując żądania robotników. Wszelako to jego środkowe miejsce, miejsce przy mikrofonie, moga zajmować również inni, tacy, których można by określić mianem złych parezjastów. Z jednej strony - na co wskazywał już Foucault - sa to wszelkiego rodzaju demagodzy i pochlebcy, którzy pragna jedynie przypodobać się rządzącym. Z drugiej, ci, którzy zdaja się posiadać cechy właściwe parezjaście: ich słowa maja przełamywać status quo, moga oni również szczycić się posiadaniem pewnego etosu, nawet pewnej odwagi mimo to jak gdyby odwracają oni strumień dźwięku i swojej „zdarzeniowej” mowy nie kieruja do rządzących, ale do rządzonych - nie widzą się w roli narzędzia zbiorowości czy choćby pierwszych pośród równych, ale wyłącznie w roli (nowych) pasterzy. Być może to jeden z tych momentów, które okazały się zgubne dla rozwoju egalitarnych tendencji młodej „Solidarności”: w czasie I Krajowego Zjazdu nie przemawiało się już do rządzących, lecz do rządzonych, a celem było nie tylko ustalenie programu, ale również zdobycie pozycji w Związku. Parezja ustapiła miejsca pozyskiwaniu elektoratu (czyli dokładnie tej samej praktyce, jaką stosowali w Stoczni KPN-owcy i inni).

Oczywiście nie ma nic złego w propagandzie, w zabieganiu o głosy (moim celem nie jest żadnego rodzaju moralizowanie), liczy się wyłącznie jego użycie. Nie musi ono także opierać się wyłącznie na kłamstwie - podział na ciemny lud, który wierzy w łgarstwa populistów, oraz obytą, wykształconą i kulturalną klasę średnią, którą można przekonać rzeczowymi, odwołującymi się do faktów argumentami, już dawno powinien zostać wymazany z lewicowej mentalności. Przeciwnie, być może rządzi się przede wszystkim za pomoca prawdy (oczywiście pozostaja pytania o to, jaka to prawda, np. odwołująca się do regularności czy zdarzeniowa? Manifestowana przez jednostkę czy oparta na jakimś wyższym porządku - boskim lub instytucjonalnym?). Kłopot związany z propaganda wynika z kierunku nadawania przekazu: zwykle mówiący zajmuje pozycję dominująca, a słuchający podporządkowaną. Dyskurs płynie z góry - nieważne czy od członków Konfederacji Polski Niepodległej, czy też od rewolucyjnej awangardy (mam oczywiście na myśli przede wszystkim dzisiejszych sukcesorów obu tych grup). Problem, na jaki natrafiłem, pisząc ten artykuł, problem, który chciałbym podkreślić ze szczególną mocą tu, na koniec, a który trzeba będzie opracować gdzie indziej, brzmi: jak egalitarnie prowadzić propagandę? Czy możliwe jest takie jej ustrukturyzowanie, by mówiący sytuował się na tym samym poziomie co słuchający? By jego mowa nie odwoływała się do transcendentnych instytucji, ale do prowadzonej 
egzystencji, zaś dyskurs nie korzystał z zastanych regularności, lecz wprowadzał zaburzające strukturę zdarzenie? Mówiąc jeszcze inaczej: czy możliwa jest propaganda oparta na parezjie Ten pośpiech i ta niezwykła intensywność, z jaką umierający Foucault mówił o cynikach kreśląc niezwykła, transhistoryczną figurę sposobu życia prowadzonego tak przez Diogenesa z Synopy, jak i dziewiętnastowiecznych rewolucjonistów (Foucault 2012, 157-190) - pozwala przypuszczać, że to właśnie tu, w etyce należy szukać wskazówek pozwalających rozwiązać ten strategiczny problem.

By spiąc cały artykuł swego rodzaju klamra, warto może raz jeszcze odnieść się do kwestii Foucaulta i sprawy polskiej. W wywiadzie, którego udzielił tuż po powrocie z objętego stanem wojennym PRL-u, podkreślał on właśnie etyczne (sam mówił: moralne, bowiem w przeciwieństwie do mnie stosował te terminy wymiennie) osiagnięcia ruchu robotniczego.

Co jest jednak godne uwagi w całej tej historii ruchu Solidarności, to fakt, że nie tylko walczono o wolność, demokrację i korzystanie z fundamentalnych praw, ale również poprzez korzystanie z praw, poprzez wolność i poprzez demokrację. [...] Kiedy mówię o nabytkach, nie mówię o wolnościach i o prawach, które mogły zostać zdobyte w danym momencie i co do których, w obecnym stanie rzeczy, możemy się obawiać, że zostaną w większości anulowane. Lecz o tym, że w zachowaniu Polaków zaistniały moralne i społeczne doświadczenia, które nie moga zostać wymazane (Foucault, w przygotowaniu).

Francuski filozof usiłuje w ten sposób powiedzieć, że walkę polityczną prowadzono przede wszystkim żyjąc w pewien określony sposób. Kształtowano egzystencję indywidualną i wspólnotową tak, jak gdyby relacje władzy już uległy zmianie. Foucault zauważa w tym miejscu to, na co później - krytykując Leninowską dyktaturę Partii - zwróci uwagę Sowa: „Forma ruchu i jego cel równoważą się” (Foucault, w przygotowaniu); „Wygląda na to, że nowy porządek społeczny może być tylko tak demokratyczny, jak demokratyczny jest wewnętrzny ruch, który doprowadził do jego ustanowienia” (Sowa 2015, 114). Dążenia polityczne muszą być podbudowane odpowiednim sposobem życia. Powiedziałbym nawet więcej: celem tych dążeń musi być przede wszystkim życie w pewien sposób, a nie posiadanie tych czy innych praw. Polityka musi być uprawiana jako etyka. 


\section{Wykaz literatury}

Abramowski, Edward. 1924. Etyka a rewolucja. W Abramowski, Edward, Pisma. Tom 1, Warszawa: Zw. Spółdzielni Spożywców Rzeczypospolitej Polskiej. (Korzystam z wersji elektronicznej dzieła: http://dir.icm.edu.pl/Pisma/Tom_1/, data dostępu: 12.04.2016).

Agamben, Giorgio. 2008. Co zostaje ₹.Auschwitæ: archiwum i swiadek. Tłum. Sławomir Królak. Warszawa: Wydawnictwo Sic!.

Beaulieu, Alain. 2010. „Towards a Liberal Utopia. The Connection Between Foucault's Reporting on the Iranian Revolution and the Ethical Turn." Philosophy and Social Criticism 7 (36): 801-818.

Deleuze, Gilles i Félix Guattari. 2015. Tysiac plateau. Red. meryt. Joanna Bednarek. Warszawa: Fundacja Bęc Zmiana.

Foucault, Michel. 2010a. The Government of Self and Others. Lectures at the Collège de France 19821983. Tłum. Graham Burchell. New York: Palgrave Macmillan.

Foucault, Michel. 2010b. Usiytek z.prayjemności. Tłum. Tadeusz Komendant. W Foucault, Michel, Historia seksualności. Gdańsk: słowo/obraz terytoria.

Foucault, Michel. 2011. Narodżiny biopolityki. Tłum. Michał Herer. Warszawa: Wydawnictwo Naukowe PWN.

Foucault, Michel. 2012. The Courage of the Truth (The Government of Self and Others II). Lectures at the Collège de France 1983-1984. Tłum. Graham Burchell. New York: Picador.

Foucault, Michel. 2013a. „Etyka troski o siebie jako praktyka wolności.” Tłum. Kajetan Maria Jaksender. W Foucault, Michel, Kim pan jest, profesorze Foucault? Debaty, rozmowy, polemiki. Kraków: Wydawnictwo Eperons-Ostrogi.

Foucault, Michel. 2013b. „Polska, a potem?” Tłum. Kajetan Maria Jaksender. W Foucault, Michel, Kim pan jest, profesorze Foucault? Debaty, rozmowy, polemiki. Kraków: Wydawnictwo Eperons-Ostrogi.

Foucault, Michel. 2014. Rzqadzenie synymi. Tłum. Michał Herer. Warszawa: Wydawnictwo Naukowe PWN.

Foucault, Michel. W przygotowaniu. „Moralne i społeczne doświadczenie Polaków nie może zostać wymazane.” Tłum. Kajetan Maria Jaksender. W Foucault, Michel, „Nie!” dla kompromisów! Krytyka, estetyka, solidarność. Kraków: Wydawnictwo Eperons-Ostrogi.

Gdańsk Sierpień '80. Rozmowy. 1990. Red. Andrzej Drzycimski, Tadeusz Skutnik. Gdańsk: Oficyna Wydawnicza AIDA. (Dokonałem na tej transkrypcji poprawek w oparciu o odbytą w mediatece Europejskiego Centrum Solidarności kwerendę audio).

Gdańsk - Sierpień 1980. Rozmowy Komisji Rzqdowej z Miedzyzaktadowym Komitetem Strajkowym w Stoczni Gdańskiej (23-31 sierpnia 1980 r.). 1981. Transkr. Mirosław Chojecki. Warszawa: Instytut Wydawniczy Związków Zawodowych.

Gdula, Maciej. 2015. „Gdula o książce Sowy: Boleśnie polska.” Recenzja książki Inna Ržeczpospolita jest możliwa! Widma przeszłości, wizje przyszłości Jana Sowy.

http://www.krytykapolityczna.pl/artykuly/opinie/20150429/gdula-o-ksiazce-sowybolesnie-polska-i-peryferyjna.

Giełżyński, Wojciech i Lech Stefański. 1981. Gdańsk sierpień 80. Warszawa: Książka i Wiedza.

Goodwyn, Lawrence. 1992. Jak to zrobiliście? Powstanie Solidarności w Polsce. Tłum. Katarzyna Rosner. Gdańsk: Krajowa Agencja Wydawnicza.

Gwiazdozbiór w „Solidarności”. Joanna i Andrzej Gwiazdowie w rozmowie z. Remigiuszem Okraska. 2009. Łódź: Obywatel.

Hoffman, Marcelo. 2014. Foucault and Power: The Influence of Political Engagement on Theories of Power. London-New York: Bloomsbury. 
Kowalik, Tadeusz. 1983. Próba kompromisu (o Komisji Ekspertów MKS w Gdańsku). Warszawa: Biblioteka Tygodnika Wojennego.

Machcewicz, Anna. 2015. Bunt. Strajki w Trójmieście. Sierpień 1980. Gdańsk: Europejskie Centrum Solidarności.

Paras, Eric. 2006. Foucault 2.0: Beyond Power and Knowledge. New York: Other Press.

PZPR a „Solidarnośc” 1980-1981: tajne dokumenty Biura Politycznego. 2013. Warszawa: Instytut Pamięci Narodowej. Komisja Ścigania Zbrodni Przeciwko Narodowi Polskiemu.

Siermiński, Michał. 2015. „Nie ma »Solidarności« bez polskości.” Recenzja książki Inna Ržeczpospolita jest možliwa! Widma pržesz̧ości, wizje przyyszłości Jana Sowy. Bez Dogmatu 104. (Korzystam z internetowej wersji tekstu: http:/ / lewica.pl/index.php?id=30822, data dostępu: 12.04.2016).

Sloterdijk, Peter. 2014. Musisz życie swe odmienic. O antropotechnice. Tłum. Jarosław Janiszewski. Warszawa: Wydawnictwo Naukowe PWN.

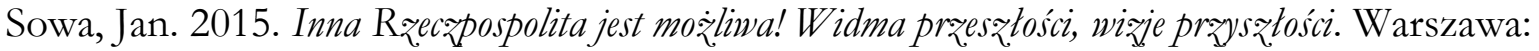
Grupa Wydawnicza Foksal. 
Cezary Rudnicki - ur. 1986, redaktor i współzałożyciel Machiny Myśli (http://machinamysli.org/), internetowego portalu popularyzującego filozofię; doktorant w Zakładzie Historii Filozofii Współczesnej UW, gdzie przygotowuje rozprawę poświęconą etyce Siebie; filozoficzny „systemowiec”, który nie cierpi specjalizacji - z tego powodu praktykuje naukowy „chaos”, czyli wielokierunkowe stawanie-się: aktualnie zajmuje się poststrukturalizmem oraz koncepcjami Nietzschego i Abramowskiego, które uzupełnia lektura pism chrześcijańskich świętych i mistyków oraz współczesnych myślicieli włoskich i niemieckich.

\section{DANE ADRESOWE:}

Instytut Filozofii

Uniwersytet Warszawski

Krakowskie Przedmieście 3

00-927 Warszawa

EMAIL: togashi.furebo@gmail.com

CYTOWANIE: Rudnicki, Cezary. 2016. Jeśli mówić prawdę, to tylko w Sierpniu. Etyka jako polityka. Praktyka Teoretyczna 4(22): 171-200.

DOI: $10.14746 /$ prt.2016.4.9

\section{AUTHOR: Cezary Rudnicki}

TITLE: Speak the truth, but only in August. Ethics as politics

ABSTRACT: In the following article I would like to join my voice with Jan Sowa's attempt to recoup the phenomenon of the "Solidarity movement" for the left. At the same time I would like to make a similar venture to recoup the 'late' thought of Michel Foucault. Whereas concepts such as discipline and biopolitics, the method of genealogical analysis of the relations of power, and even a concept of the entrepreneurial self, have been already adopted by the left, the considerations centered around issue of 'the care of the self and the others' are treated usually as a curiosity. This silence has been used by the liberal commentators of Foucault, as well as a foundation for the neoconservative project of Peter Sloterdijk (whose core was presented in an extensive essay You Must Change Your Life). It is all the more worrying, since Foucault saw the most important point of resistance to neoliberalism precisely in the ethics of the Self. The analysis of the events of Polish August '80, carried out in the following text by means of some of the concepts developed in 1980-1984 by the 
French philosopher, is also an attempt to indicate usefulness of these concepts for the revolutionary practice and theory.

KEYWORDS: parrhèsia, Polish August 1980, ethics, Solidarity, Foucault, practices of the self. 